\title{
Language and Culture in
}

\section{Eighteenth-Century Russia}


Studies in Russian and Slavic Literatures, Cultures and History

Series Editor — Lazar Fleishman (Stanford University)

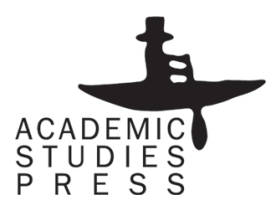




\section{Victor Zhivov}

\section{Language and Culture in}

\section{Eighteenth-Century Russia}

Boston

2009 
Library of Congress Cataloging-in-Publication Data

Zhivov, V. M.

[IAzyk i kul'tura v Rossii XVIII veka. English]

Language and culture in eighteenth-century Russia / by Victor Zhivov; translated by Marcus Levitt. p. cm. - (Studies in Russian and Slavic literatures, cultures and history)

Includes bibliographical references and index.

ISBN 978-1-934843-12-3 (alk. paper)

1. Russian language - 18th century-History. 2. Russia-Civilization-18th century. 3. Russian language - Style. 4. Language and culture-Russia-History-18th century. I. Levitt, Marcus C., 1954 - II. Title. III. Title: Language and culture in 18th century Russia.

PG2075.Z4813 2009

491.709’033-dc22

2009020250

The book is supported by Mikhail Prokhorov Foundation (translation program TRANSCRIPT).

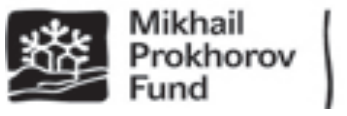

Copyright (C) 2009 Academic Studies Press

Cover design by Samuel Volchek

Published by Academic Studies Press

28 Montfern Avenue

Brighton, MA 02135, USA

www.academicstudiespress.com 


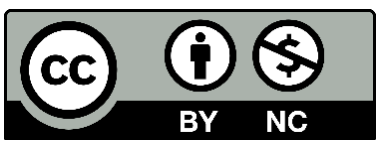

Effective December 12th, 2017, this book will be subject to a CC-BY-NC license. To view a copy of this license, visit https://creativecommons.org/licenses/by-nc/4.0/. Other than as provided by these licenses, no part of this book may be reproduced, transmitted, or displayed by any electronic or mechanical means without permission from the publisher or as permitted by law.

The open access publication of this volume is made possible by:

THE

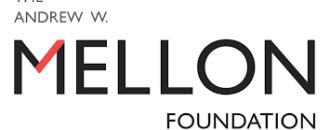

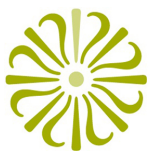

NATIONAL ENDOWMENT FOR THE HUMANITIES

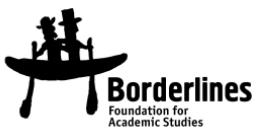

This open access publication is part of a project supported by the National Endowment for the Humanities and The Andrew W. Mellon Foundation Humanities Open Book initiative, which includes the open access release of several Academic Studies Press volumes. To view more titles available as free ebooks and to learn more about this project, please visit borderlinesfoundation.org/open.

Published by Academic Studies Press

28 Montfern Avenue

Brighton, MA 02135, USA

press@academicstudiespress.com

www.academicstudiespress.com 